\title{
Harrastus tekniikan historian tutkimuksen tukena
}

\author{
Veijo Kauppinen'
}

Filatelistien kokoelmat eivät ensimmäisenä tule mieleen tekniikan ja teollisuuden historian tietolähteinä. Sattuvimmillaan ne kuitenkin ovat juuri sitä. ${ }^{2}$ Hyvä esimerkki on kommodori evp. Kai Varsion vuonna 2015 julkaisema väitöskirja, joka käsittelee postimerkkejä dokumentteina Britannian ja Saksan laivastojen varustelusta maailmansotien välisenä aikana. ${ }^{3}$

Hyvä esimerkki teollisuushistorian näkökulmasta kiinnostavista taustoista on Filatelistilehden numerossa 7/2020 päätoimittajan haastatteluna julkaistu artikkeli, jossa käsitellään Kuopion vanhimpaan kauppataloon Gust. Raniniin ja siihen liitetyn Lignell \& Piispasen panimon sekä väkijuomatehtaan vaiheita ${ }^{4}$. Filatelisti-näkökulma aiheeseen on Raninin sukuun avioituneen Harry Dunkelin keräämä postimerkkikokoelma. Dunkel sai idean kokoelmasta yhtiöstä löytyneistä asiakirjoista muutettua yrityksen johtotehtäviin Kuopioon. Hän täydensi sitä alan kauppiailta sekä huutokaupoista tehdyillä hankinnoilla.

Artikkelista selviää, että Ranin (1825-96) aloitti liiketoimintansa 1850-luvun puolivälissä ostamalla maaseudulta voita, talia sekä tervaa, jotka hän toimitti Pietariin vaihdettavaksi siellä maaseudulla tarvittaviin suolaan, sokeriin ja kahviin. Koska tällainen tukkukauppa edellytti kuljetuskapasiteettia, Ranin oli mukana useissa laivayhtiöissä. Dunkelilla onkin myös sisävesien liikennettä käsittelevä kokoelma Vuoksen vesistön kehittyminen ja matkustajalaivaliikenne vuoteen 1892. Liikeasiakirjoja, kirjeenvaihtoa sekä selkeitä sisävesiemme laivaliikenteen reittikarttoja sisältävän kokoelman kokoaminen on vaatinut runsaasti tutkimustyötä5. On pitänyt tarkistaa laivojen aikataulut, satamat ja laiturien paikat sekä mikä laiva kulloinkin on ollut liikenteessä. Tiedot on etsitty paitsi Kansallisarkistosta ja sanomalehdistä myös Postin kiertokirjeistä. Oman kokoelmansa muodostavat laivaleimat, joiden osalta kohteiden löytäminen etenkin Laatokan alueelta on osoittautunut haastavaksi.

Antti Roivaisen Filatelisti -lehden numerossa 8/20 julkaistu artikkeli 150-vuotiaasta Riihimäki-Pietarin-radasta on sekin kiinnostava tekniikan historian näkökulmasta. ${ }^{6}$ Artikkelisarjan ensimmäinen osa sisältää tarkan kuvauksen jokaisesta asemasta asemarakennuksineen lähtien Pietarista Suomeen puolelle. Artikkelin jatko-osa kuvaa Venäjän puoleisia asemia. Rata oli sekä postin kulun että lennättimen takia tiedonvälityksen avainasemassa. Artikkelista selviää muun muassa, että Asema no. 29 "Hikiä" esiintyi aluksi muodossa "Hikie" johtuen sijainnista ilmastollisesti edullisessa paikassa Salpausselän rinteessä. Nimi viitannee lämpimyyteen eli hikeyteen. Kouvolan asemalla oli puolestaan vain vähäinen merkitys ennen kuin siitä muodostui rautatien risteysasema, mutta Kaipiainen oli tärkeä maanteiden risteysasema. Laaja artikkeli on kattavasti kuvitettu.

\footnotetext{
${ }^{1}$ Kirjoittaja on Teknillisen korkeakoulun, nyk. Aalto-yliopiston emeritusprofessori.

${ }^{2}$ Kauppinen, 2009.

${ }^{3}$ Varsio, 2015.

${ }^{4}$ Poropudas, Lauri. 2020. Harri Dunkelin mielenkiintoinen postihistoria. Filatelisti 7: 10-19.

5 Poropudas, 2020.

${ }^{6}$ Roivainen, 2020.
} 
Kuva 1. Lähde: Poropudas, Lauri. 2020. "Harri Dunkelin mielenkiintoinen postihistoria". Filatelisti 7/20: 10-19

Tämä Filatelisti-lehden artikkeli johdattelee rautatiehistoriaan, johon liittyy myös monille yllättävä tieto on satusedäksi ja romaanikirjailijaksi mielletyn $\mathrm{Z}$. Topeliuksen palavasta kiinnostuksesta aikansa modernia tekniikkaa kohtaan. Euroopan matkojensa kokemuksen perusteella hän ymmärsi maantie- ja rautatieliikenteen sekä tiedotusvälineiden tärkeyden maan kehittymiselle. Hänen perustelunsa saattoivat jopa syrjäyttää J. V. Snellmannin ajaman kanavaverkoston rakentamisen. ${ }^{7}$ Tosin Topeliuksenkin kannanotoista tuli hankkeiden kasvavien kustannusarvioiden myötä varovaisempia. Tämä toki oli aikansa nykypäivää, tulevaa historiaa.

Rautateiden lisäksi myös maantiet olivat varhaisia postin kuljetusreittejä. Erityisen mielenkiintoinen on Tukholma-Riika -yhteyttä postiasemineen vuosina 1638-39 käsittelevän artikkelin osa 4 Helsingistä Viipuriin. ${ }^{8}$ Santahaminasta kaavailtiin Uudenmaan ja Hämeen tapulikaupunkia, jolloin Helsinki ja Porvoo olisivat jääneet maalaiskaupungeiksi. Ylempi Viipurintie eli Hämeenlinnan Härkätie kulki pohjoisempana.

Filatelisti-lehden numeroissa $1 / 20$ sekä 2/20 ilmestynyt Christian Jokisen kaksiosainen artikkeli käsittelee puolestaan kolmannen valtakunnan postimerkkejä, jotka heijastavat kansallissosialismin näkemystä myös teknologiasta. Vuosina 1933-1945 ilmestyneissä saksalaisissa postimerkeistä tavataan neljä kansallissosialistisen ideologian selkeää elementtiä, johtajakultti, nuorison aatteeseen sitouttaminen, teknisen kehityksen ihailu sekä militarismi. Kahta jäkimmäistä edustavat vuosina 1943-1944 julkaistut, yhteensä kahdenkymmenenviiden merkin Saksan taisteluvoimaa esitelevät kaksi Wehrmacht-sarjaa. Artikkelin toisen osan aiheet perustuvat

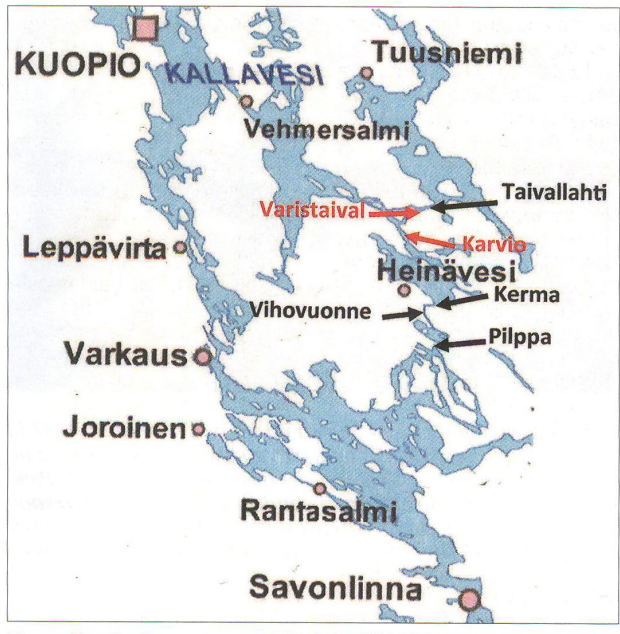

Harry Dunkelin molemmissa laivakokoelmissa on hienona apuna selkeät kartat, joista asiaa tuntematonkin saa käsityksen, missä mennään. Tässä viimeisenä valmistunut Juojärvelle menevä väylä, jota pitkin pääsee Tuusniemelle ja Kaaville asti. Varistaival valmistui 1913 ja sen yläpuolella oleva Taivallahden kanava 1914.

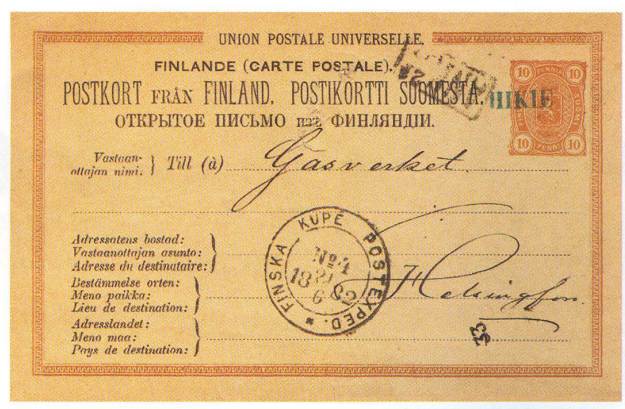

Ehiökortti Hikiältä Helsinkiin 24.6.1882. Oikealla ylhäällä on HIKIE-asemaleima sekä ylösalaisin ANK-tuloleima. Keskellä on postivaunun 4 leima ja oikealla alhaalla asemanumero 33, jota käytettiin Hikiältä lähteneessä postissa marraskuusta 1881 vuoteen 1889.

Kuva 2. Lähde: Roivainen, Antti. 2020. "Pietarin radan ensimmäiset liikennepaikat".

Filatelisti 8/20: 9-23

\footnotetext{
${ }^{7}$ Kauppinen, 2020; Meinander, 2020.

${ }^{8}$ Gustavsson, 2017.
} 


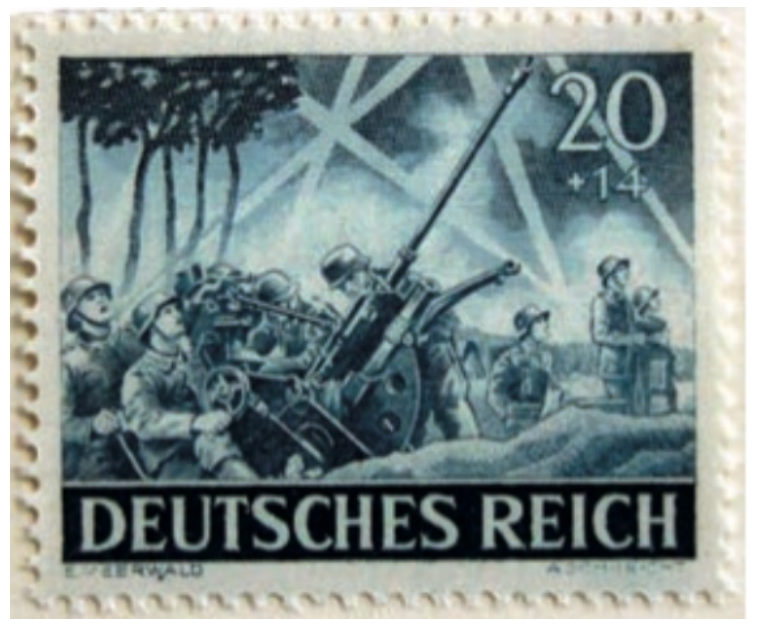

Kuva 3. Rheinmetallin $200 \mathrm{~mm}$ kaliberinen ilmatorjuntatykki kuului myös Suomen armeijan kalustoon tunnuksella $20 \mathrm{ltK} / 30 \mathrm{BSW}$. Talvisodan alla niitä ostettiin 50 ja myöhemmin lisää. Vuonna 1960 niitä oli vielä inventaariossa 142. Kuvan tykin taustalla valonheittimien kiilat etsivät kohteita. Lähde: Jokinen, Christian. 2020. "Kolmannen valtakunnan postimerkit, osa 1." Filatelisti 1/20: 46-48.

propagandakuviin ja ykkössarjan Deutsches Reich on jo korvattu tekstillä Grossdeutsches Reich (Suursaksa). Sitä esittelevä osa on tulevaa toteavasti alaotsikoitu "Rintama murenee, valtakunta suurenee".

Aseteknisesti tarkoin analysoitujen merkkien aiheet esittävät sodan "perustyökaluja", eivät saksalaisten asekehityksen vuosien 1943-1944 viimeisimpiä saavutuksia. Propagandassa käytettyjä "ihmeaseita" tai "kostoaseita" niissä ei esiinny. Suomalaisia merkeistä kiinnostanevat meidän sotakalustoomme kuluneet Nebelwerfer -raketit, BSW -ilmatorjuntatykit, Panzer ja Sturmgeschütz -hyökkäysvaunut sekä Stuka-syöksypommittajat ja vuoristojääkärit.

\section{Lähteet:}

Gustavsson, Per. 2017. "Tukholma-Riika 1638-39", osa 4. Filatelisti 6/17: 28-35.

Jokinen, Christian. 2020. "Kolmannen valtakunnan postimerkit, osa 1." Filatelisti 1/20: 46-48.

Jokinen, Christian. 2020. "Kolmannen valtakunnan postimerkit, osa 2". Filatelisti 2/20: 44-47.

Kauppinen, Veijo. 2009. "Tekniikan historiaa postimerkeillä". Tekniikan Waiheita 1: 44-49

Kauppinen, Veijo. 2020. "Satusetä ennakoi teknistä kehitystä". Tekniikan Historia 5: 22-29.

Meinander, Henrik. 2020. Kaleidoskooppi. Tutkielmia Suomen historiasta. Helsinki: Siltala.

Poropudas, Lauri. 2020. "Harri Dunkelin mielenkiintoinen postihistoria". Filatelisti 7/20: 10-19

Roivainen, Antti. 2020. "Pietarin radan ensimmäiset liikennepaikat". Filatelisti 8/20: 9-23

Varsio, Kai. 2015. Postimerkit merisotataidon dokumentteina, Britannian ja Saksan laivastojen varustelu maailmansotien välisenä aikana. Diss. Maanpuolustuskorkeakoulu, Sotatekniikan laitos. 